\title{
Into College, Out of Poverty? Policies to Increase the Postsecondary Attainment of the Poor
}

\section{Citation}

Deming, David, and Susan Dynarski. 2009. "Into College, Out of Poverty? Policies to Increase the Postsecondary Attainment of the Poor" (September). NBER Working Paper. doi:10.3386/w15387. http://dx.doi.org/10.3386/w15387.

\section{Published Version}

10.3386/w15387

\section{Permanent link}

http://nrs.harvard.edu/urn-3:HUL.InstRepos:12305833

\section{Terms of Use}

This article was downloaded from Harvard University's DASH repository, and is made available under the terms and conditions applicable to Other Posted Material, as set forth at http:// nrs.harvard.edu/urn-3:HUL.InstRepos:dash.current.terms-of-use\#LAA

\section{Share Your Story}

The Harvard community has made this article openly available.

Please share how this access benefits you. Submit a story.

\section{Accessibility}


NBER WORKING PAPER SERIES

INTO COLLEGE, OUT OF POVERTY? POLICIES TO INCREASE THE POSTSECONDARY ATTAINMENT OF THE POOR

\author{
David Deming \\ Susan Dynarski \\ Working Paper 15387 \\ http://www.nber.org/papers/w15387 \\ NATIONAL BUREAU OF ECONOMIC RESEARCH \\ 1050 Massachusetts Avenue \\ Cambridge, MA 02138 \\ September 2009
}

We thank the Robin Hood Foundation for supporting this research. The views expressed herein are those of the author(s) and do not necessarily reflect the views of the National Bureau of Economic Research.

(C) 2009 by David Deming and Susan Dynarski. All rights reserved. Short sections of text, not to exceed two paragraphs, may be quoted without explicit permission provided that full credit, including $\odot$ notice, is given to the source. 
Into College, Out of Poverty? Policies to Increase the Postsecondary Attainment of the Poor David Deming and Susan Dynarski

NBER Working Paper No. 15387

September 2009

JEL No. H52,I22,I28,J24,J38

\section{ABSTRACT}

We review the experimental and quasi-experimental research evidence on the causal relationship between college costs and educational attainment, with a particular focus on low-income populations. The weight of the evidence indicates that reducing college costs can increase college entry and persistence. Simple and transparent programs appear to be most effective. Programs that link money to incentives and/or the takeup of academic support services appear to be particularly effective.

David Deming

Harvard University

Kennedy School of Government

79 JFK Street

Cambridge, MA 02138

demingd@nber.org

Susan Dynarski

University of Michigan

Weill Hall

735 South State Street

Ann Arbor, MI 48109-3091

and NBER

dynarski@umich.edu 


\section{Introduction}

College-going has risen substantially over the past forty years. In 1968, 36 percent of 23year-olds had gone to college, while by 2005, that figure had grown to 58 percent. ${ }^{1}$ But these gains have been uneven. African-Americans are about half as likely as non-Hispanic whites to earn a bachelor's degree (19 percent vs. 37 percent) and Hispanics less than one-third as likely (11 percent). ${ }^{2}$ Females are about twelve percentage points more likely to have attended college by age 23 (64 versus 52 percent), and about seven percentage points more likely to have completed a BA (32 versus 25 percent.)

Some of these differences trace back to performance gaps in elementary school and high school. But even among those who do well on achievement tests, socioeconomic inequalities remain: 74 percent of high-scorers who grew up in upperincome families complete college, compared to only 29 percent of those who grew up in low-income families (College Board, 2005).

While thirty years ago a high school degree was sufficient for financial security, it is now a college degree that is the key to a middle-class lifestyle. Since the 1970s, high school dropouts and graduates have lost ground, with their real earnings dropping substantially (Figure 1, from College Board, 2005). Typical earnings for a full-time, male high school graduate in 1972 were $\$ 45,000$ (in constant 2003 dollars). That figure had dropped by a third $(\$ 30,000)$ by $2005 .^{3}$ By contrast, real earnings for the college-educated have held steady; among women, they have risen.

These two sets of trends - steady earnings for those with a college education, plunging earnings for those without - mean that college is increasingly important to financial well-being.

\footnotetext{
${ }^{1}$ Authors' calculations from the October Current Population Survey.

${ }^{2}$ Authors' calculation of BA completion rates for 25-26 year olds in the 2005 CPS.

${ }^{3}$ Over the same period, earnings among male, high school dropouts plunged from $\$ 40,000$ to $\$ 22,000$.
} 
In 1972, men with a bachelor's degree typically earned 22 percent more than those with a high school degree. By 2003, this return had nearly tripled, to 60 percent.

In light of the rising importance of a college degree, policymakers have focused on increasing college enrollment as an important tool for mitigating poverty. This chapter reviews the evidence on a key tool available to policymakers - reducing college costs. Section II briefly

outlines the policy context; Section III reviews the evidence from experimental and high-quality quasi-experimental studies of college cost reduction; Section IV discusses the broad lessons derived from these studies and concludes.

\section{Policy context}

Colleges, state and federal government and private organizations spend billions to subsidize college costs. In this section, we briefly describe the major programs.

Two federal programs provide the bulk of aid to college students: the Pell Grant and the Stafford Loan. Pell Grants flow almost exclusively to families with incomes below \$40,000 (Stedman, 2003). During the 2004-05 academic year, \$13.6 billion in Pell Grants was delivered to over five million students (College Board, 2005). During the same year, \$55 billion in loans was delivered to undergraduates through the Stafford Loan program.

States hold down college costs by subsidizing public universities, which in turn charge lower tuition prices than their private counterparts. The vast majority of students attend public colleges, so this is an important channel through which government subsidizes college costs. In addition to charging artificially low prices to all students, states also offer scholarships to individual students. Most of these are small-scale programs, but beginning in the early 1990s, more than a dozen states established broad-based merit aid programs. These programs typically 
award full tuition and fees at state public universities (or in some cases, an equivalent voucher to attend a private school) to residents who maintain a minimum high school grade point average. Many require a grade point average of 3.0, not a particularly high threshold - Dynarski (2004) calculates that in 1999, 40 percent of high school seniors met this standard.

In recent years, the federal and state tax codes have also been used as a vehicle for subsidizing college costs. The Hope and Lifetime Learning tax credits and the deduction for college tuition and fees help families pay for current college costs. Parents can also claim children under 24 as dependents if they are enrolled in college. The federal Coverdell Education Savings Account and the state 529 savings plans help families pay for college in the future by increasing their after-tax returns on savings. With a total cost of $\$ 10.5$ billion, these education tax incentives approach spending on the Pell Grant, historically the cornerstone of federal aid for college students (College Board, 2005). But, as they are currently configured, these programs almost exclusively benefit upper income families (Dynarski, 2004; Dynarski and Scott-Clayton, 2006a) and so are not candidate instruments for reducing poverty.

Foundations and colleges are additional sources of student aid. Programs such as the Gates Millenium Scholars, the I Have a Dream foundation, and Kalamazoo Promise fully sponsor college attendance (or "top up” the difference between government grants and estimated need) for low-income and/or minority students. Although these programs are small in scale compared to the federal and state aid programs discussed above, they are highly visible and intended to increase college attendance, and so we will discuss them in the chapter.

We will not examine the new and widely-discussed scholarship programs of elite colleges (such as Harvard and Princeton) which offer a free ride for low-income students (Pallais and Turner, 2007, Avery et al, 2006; Linsenmeier et al 2006; Rothstein and Rouse 2007, van der 
Klaauw 2002). Helping low-income students make the leap from high school into any college is the critical task if the goal is poverty reduction, and these programs do not serve this function. The low-income student who takes up Princeton's offer of a free ride would likely have gone to Harvard (or Berkeley) had Princeton not been so generous. Convincing more nonwhite and lowincome students to attend Princeton instead of Berkeley may serve important social goals, such as diversifying our political leadership (Bok and Bowen, 2000), but poverty reduction is not among them.

Most evaluations of the programs we have mentioned focus on the enrollment margin. However, while enrollment has risen substantially over the past forty years, degree receipt has barely budged (Turner, 2006). Thus retention and graduation of college enrollees has also become an important policy issue. We review evidence from several recent experimental evaluations that provide scholarships and services to existing college enrollees. These programs are of particular interest since they focus on marginal students, for whom retention rates are lowest.

\section{Evidence}

Economic theory (and common sense) predicts that lowering the price of college will increase attendance. While the theoretical prediction is clear, students' marginal responsiveness to additional dollars of aid is an empirical question. Answering this question is a challenge, since eligibility for subsidies is certainly not random and is likely correlated with unobserved determinants of schooling. As a result, estimates based on the cross-sectional correlation of aid with schooling are subject to multiple sources of bias. 
A long empirical literature examines the effect of college costs on schooling decisions. Leslie and Brinkman (1988) review more than seventy of these studies. ${ }^{4}$ With few exceptions, discussed below, this long literature suffers from a key limitation: the response of schooling to price is poorly identified. That is, the variation in schooling prices used to estimate the parameter of interest is likely to be correlated with the unobserved determinants of schooling.

More formally, the relationship between financial aid and schooling decisions can be expressed with the following equation:

$$
S_{i}=\alpha+\beta \text { Aid }_{i}+\varepsilon_{i}
$$

Here, $S_{i}$ is some measure of an individual's schooling, such as college attendance or completed years of college, $A_{i d}$ is the amount of student aid (expressed in dollars) for which an individual is eligible, and the error term $\varepsilon_{i}$ represents the unobserved determinants of schooling. If aid is uncorrelated with $\varepsilon_{i}$, then $\beta$ can be interpreted as the effect of an additional dollar of aid on college attendance or completed education.

If financial aid is randomly assigned in an experimental setting, $A_{i d}$ is uncorrelated with $\varepsilon_{i}$. In nearly all nonexperimental studies, however, aid is offered to students on the basis of characteristics that independently affect the probability of college attendance. For example, the federal government uses the Pell Grant to increase the college attendance of low-income youth. If such students are relatively unlikely to attend college, perhaps because of low levels of parental education or poor secondary schooling, then estimates of $\beta$ based on this source of variation in aid will be biased downward. Conversely, since many colleges use merit

\footnotetext{
${ }^{4}$ Heller (1997) updates this review with studies done after Leslie and Brinkman (1988.)
} 
scholarships to attract high-achieving students, $\beta$ could be biased upward if such scholarships are included in the analysis.

One can attempt to correct for this bias by controlling for observed determinants of schooling (such as parental income or academic achievement) in a vector of regressors $X_{i}$ :

(2) $\quad S_{i}=\alpha+\beta \operatorname{Aid}_{i}+\delta X_{i}+\varepsilon_{i}$

If $X_{i}$ is sufficiently rich that it captures all other sources of variation in individual schooling decisions and schooling costs, then $\beta$ will be unbiased. However, under plausible conditions this approach will fail, for two reasons:

- Complete data on relevant characteristics is rarely available. For example, parental wealth affects schooling decisions, both directly and through eligibility for aid, but comprehensive measures of parental (and extended family) wealth are rarely present in survey data, especially among adults who have completed their education.

- Even if all relevant variables are available, their role in the schooling decision may not be properly modeled. Theory provides little guidance as to which attributes should be held constant in estimating Equation (2). This is particularly problematic because point estimates in this literature are often quite fragile, even changing sign with small changes in specification. As a practical example, the effect of income on Pell Grant eligibility is highly nonlinear, and unless the functional form of the underlying relationship between income and schooling is perfectly specified, the resulting estimate will be biased. 


\section{B. Quasi-experimental studies}

We now discuss analyses of natural (or quasi-) experiments, in which a discrete shift in aid policy affects one group of individuals but not others. Beginning with Hansen (1983), who examined the introduction of the Pell Grant in the early 1970s, a small but growing number of studies has used this approach to estimate the effect of schooling costs on college-going. We summarize the main results of these studies in Table I.

\section{Federal Programs}

Most of these studies examine the effect of grant aid. Studies which examine the Pell Grant, currently the largest source of federal grant aid, produce mixed results: Hansen (1983) and Kane (1995) found no effect of the introduction of the Pell on the college enrollment rate of lowincome recent high school graduates. Seftor and Turner (2002) use a differences-in-differences framework to examine the effect of changing Pell Grant eligibility rules, and find that "nontraditional” students are about 4 percentage points more likely to attend college once they are considered eligible. Bettinger (2004) uses a regression-discontinuity approach to look at the effect of the Pell Grant on persistence using a sample of college students; his estimates are extremely sensitive to specification.

Veterans' educational benefits have historically been one of the largest sources of grant aid for college in the US. Since children from poor families are more likely than others to enroll in the military, programs that increase veterans' education have the potential to reduce poverty. Multiple studies of the post-World-War-II GI Bills (Angrist, 1993; Stanley, 2003; Turner and Bound, 2003; Bound and Turner, 2003) have found these benefits to have raised schooling levels substantially. 
Evaluating another federal program, Dynarski (2003) concludes that an additional \$1000 in aid increases college attendance by about four percentage points. She examines the elimination of the Social Security student benefit program, which paid the college costs of the children of deceased, disabled or retired Social Security beneficiaries. Eligible students were disproportionately poor, nonwhite and from single-parent families, so these estimates are quite relevant. Dynarski uses the death of a parent during a person's childhood as a proxy for Social Security beneficiary status, and finds that college attendance of the affected group dropped by more than a third, and schooling by two-thirds of a year.

While loans are the dominant form of federal aid today, we unfortunately know little about how they affect behavior. Reyes (1995) examines the effect of relative changes in loan eligibility across income groups in the early eighties, and concludes that loan access increases attendance and completed schooling. Dynarski (2005) addresses this question using variation in loan eligibility induced by the Higher Education Amendments of 1992, which removed home equity from the set of assets "taxed" by the federal aid formula. She finds a small effect of loan eligibility on college attendance and a larger effect on the choice of college.

\section{State Programs}

Subsidized public tuitions, which vary considerably by state, are one of the largest sources of education subsidies. Estimates based on cross-sectional variation in tuition may be biased, since states with a preference for education may have both low tuition prices and high college attendance rates. The solution of Kane (1995) is to use state fixed effects; his identifying assumption is that within-state changes in tuition prices are uncorrelated with changes in a state's 
taste for college. He concludes that a $\$ 1,000$ drop in public tuition produces about a four percentage point increase in college attendance rates of recent high school graduates.

Several studies have used the introduction of state merit scholarship programs as a source of variation in schooling costs. Dynarski (2000) and Cornwell, Mustard and Sridhar (2006) conclude that the Georgia HOPE scholarship increase college attendance by 4-6 percentage points per $\$ 1000$ in grant aid. Dynarski (2004) finds that a dozen states' scholarship programs have had similar, but slightly smaller effects, and that their positive effects on college attendance are greater for nonwhites. Kane (2003) uses a regression discontinuity approach to examine the CalGrant, and finds substantial impacts on college entry for students who had already applied for financial aid. Abraham and Clark (2006) and Kane (2007) evaluate the DC Tuition Assistance Grant program, which allowed DC residents to pay in-state tuition at public schools across the country. They find that the fraction of DC residents that attended Maryland and Virginia schools more than doubled, and estimate an impact on overall enrollment of 3-4 percentage points per $\$ 1000$ of effective tuition reduction. Goodman (2008) examines a program in Massachusetts that assigns aid on the basis of a standardized test score, and finds that the scholarship induced 6 percent of winners to switch from private to public 4-year colleges. He also finds that lowincome (and low test-score) students are more price sensitive. However, there was no impact on overall enrollment.

Dynarski (2008) finds that the Georgia and Arkansas merit scholarship programs have also increased degree completion, by around 3-4 percentage points. She estimates that the scholarships increases persistence by 5-11 percent for those who would have entered college anyway. This suggests that the positive effect of lower cost on retention outweighs any negative effect of enrolling marginally weaker students who are less likely to persist. 
Finally, a recent paper by Scott-Clayton (2009) examines the impact of the PROMISE scholarship, a merit aid program in West Virginia. The PROMISE scholarship was similar to other state merit programs in its initial eligibility requirements and the amount of aid it offered. But it was unique in requiring students to complete at least thirty credits per year in order to keep their scholarships, a rate which would put them on track to graduate in four years. She finds that PROMISE increased eventual graduation rates by almost 4 percentage points, while the percentage of students graduating on time increased by about 7 percentage points from a baseline of just 27 percent. The impacts on year-by-year credit completion were concentrated around the annual renewal threshold in the freshman through junior years, but disappeared in the senior year when students were still receiving their scholarships but no longer faced any renewal requirements (scholarships could not be renewed for a fifth year in any case). Scott-Clayton' concludes that incentives are a powerful play are at least as important as cost reduction suggests that a combination of cost reduction and performance incentives may have a greater impact than financial aid alone.

\section{Other Programs}

DesJardins and McCall (2007) study the impact of the Gates Millenium Scholarship (GMS) using a regression discontinuity design. GMS “tops up” the difference between needbased grants and unmet financial need for eligible minority applicants. Scholars are selected on the basis of high school record and a scored application process, which generates discontinuous changes in the probability of receiving an award. Although the evaluation is still ongoing, they 
find weak impacts on overall retention but strong evidence of decreased loan debt and work hours.

Table 1 summarizes the findings from the quasi-experimental studies discussed above. The studies in this table are those which we consider as estimating causal impacts of the effect of schooling costs on schooling decisions. Subsidies to post-secondary schooling do appear to affect schooling decisions. The best estimates suggest that eligibility for $\$ 1,000$ of subsidy increases college attendance rates by roughly four percentage points. Aid eligibility also appears to increase completed schooling and shift students from community colleges toward four-year schools.

\section{Experimental Evaluations}

One straightforward way to assess the causal impact of financial aid on college enrollment and persistence is to randomly allocate scarce scholarship funds to an eligible population. Several experimental studies have examined the effect of scholarships when they are combined with mentoring or other services. A key, unresolved question in these studies is the extent to which services, and the cost of providing them, are more effective than the scholarships.

Most randomized trials in higher education examine the effect of aid or services on grades, credit accumulation and/or persistence past the first year, conditional on enrollment. The reasons for this are largely practical - school-based interventions are more administratively feasible than tracking high school students to their chosen colleges around the country. To our knowledge, only one randomized trial looks directly at the enrollment margin. 


\section{Upward Bound}

Upward Bound is a federal and nationwide program that provides comprehensive precollege services to participants, including supplemental college-preparatory coursework in math, science, English; tutoring; counseling; and activities such as attendance at museums and plays. Mathematica Policy Research conducted a randomized trial of Upward Bound from 1992 to 1994, following participants for several years. They found weak impacts of Upward Bound on performance in high school courses (Myers and Schirm, 1999.) A more recent evaluation finds no statistically insignificant impact on college enrollment (Myers et al, 2004) though there is some evidence of substitution from 2 to 4 -year colleges. ${ }^{5}$ There is no impact on total college credits earned. ${ }^{6}$ See the paper by Long (2008) in this volume for more detail on the administration and evaluation of Upward Bound.

\section{Experimental Effects of College Persistence Programs}

About twenty percent of students who enroll at a 4-year college leave within one year. About forty percent fail to obtain a degree within six years (College Board, 2005.) Attrition is even higher at non-selective schools, where the majority of students commute from home and work part- or full-time. Since these students are more weakly attached to their institutions, policies have focused on creating a stronger connection with the college experience via more extensive mentoring, counseling, and collaborative "learning communities” (Bloom and Sommo,

\footnotetext{
${ }^{5}$ The treatment group was 5 to 6 percentage points more likely to have attended a 4-year college and 3 to 5 percentage points less likely to have attended a 2-year college than the control group.

${ }^{6}$ The evaluation does report much larger results for students with low (versus high) "educational expectations." Among students who did not expect to earn a bachelor's degree, the treatment group was about 20 percentage points more likely to attend a 4-year college than the control group, although the overall enrollment effect was still not significant. However, since this evaluation does not actually measure degree receipt, this result is difficult to interpret. Other results by subgroup are available in Myers et al (2004.)
} 
2005). Two randomized trials have evaluated the effect of such programs; we discuss them below.

\section{Student Achievement and Retention Project}

The Student Achievement and Retention Project was a large-scale randomized trial launched in 2005 at the urban campus of a major Canadian public university (Angrist, Lang and Oreopoulos 2009). Participants in the STAR experiment are similar to students at non-selective universities in the U.S. About eighty percent of the sample lived with their parents and commuted to school, and the majority planned to work part-time while enrolled. Many of the students were first- or second-generation immigrants.

Incoming freshman were randomly assigned to one of four groups. The first was offered enhanced services, in the form of peer advising and organized study groups. The second was offered a financial incentive of $\$ 5,000$ to complete a full course load with a grade point average of 3.0 or higher (the payment was $\$ 1,000$ for a GPA of at least 2.3). A third group was offered both services and a financial incentive, while a fourth group formed a control group and was offered the college's typical services.

Overall, the effect of STAR was moderate. The largest impacts were found for the group offered both services and a financial incentive. First-year grade point average increased between 0.1 and 0.2 standard deviations, and the combined group was about five percentage points less likely to be placed on academic probation. Significant effects of STAR were driven entirely by female participants - there was no effect of the program on males in any group. There was also no effect of the program for the services or scholarship-only groups. 


\section{Opening Doors}

Opening Doors is a large-scale randomized trial at six community colleges in four states run by Manpower Research Development Corporation (MDRC). Preliminary results are currently available for five of the six sites. The intervention at each site consists of "learning communities” (in which entering students take blocks of classes together and are offered extra tutoring); supplementary financial aid; and enhanced student services (extra counseling and monitoring).

The first Opening Doors evaluation occurred at Kingsborough Community College in Brooklyn, NY in the fall of 2003 (Bloom and Sommo, 2005.) The intervention targeted approximately 750 entering freshman, who were ethnically and racially diverse; many were recent immigrants that needed training in remedial English. Treatment group members were place in learning communities of about 25 students each and received textbook vouchers.

Three semesters after the program at Kingsborough Community College, the treatment group was 5.6 percentage points more likely to be enrolled in any college (Scrivener et al, 2008.). Treatment group members earned an average of 2.4 more credits and were in school about 0.1 more semesters. They were more likely to attempt and pass standardized reading and writing assessments. The effect sizes for these various assessments were around 0.1 standard deviations, but were closer to 0.2 SDs for students whose initial English skills were worse at baseline. $^{7}$

A second set of Opening Doors demonstrations took place in northern Ohio (Scrivener and Au, 2007; Scrivener and Pih, 2007.) Students were given regular appointments with an Opening Doors counselor and given a \$150 per semester scholarship that if they attended these meetings. Results were weak. There was no increase in credits attempted or earned in the initial

\footnotetext{
${ }^{7}$ For more detail on the assessments and subgroup effect sizes, see Scrivener et al (2008.)
} 
semester, nor any impact on pass rate or grade point average. However, there was an effect on retention of 5 to 10 percentage points and a small effect on earned credits.

Two Opening Doors demonstrations also took place at community colleges in New Orleans in 2004 (Brock and Ritchburg-Hayes, 2006.) In addition to the learning communities, the treatment group was offered $\$ 1000$ per semester for half-time enrollment and a $\mathrm{C}$ average. First year impacts were substantial. Opening Doors participants were about nine percentage points more likely to be enrolled full-time, and earned on average 1.1 additional credits in the first semester. They were about twelve percentage points more likely to pass and about seven percentage points less likely to withdraw from an attempted course. These effects persisted into the second and third semesters. The treatment group was about eighteen percentage points more likely to remain enrolled into the second semester and about eleven percentage points more likely to enroll for a third semester. The pass rate for enrolled courses also remained significantly higher, and there was some evidence of small grade point average increases as well. The cumulative effect of the program was a large and statistically significant increase of 3.3 credits earned, and an average gain of 0.3 semesters worth of enrollment.

Overall, the results from Opening Doors are very encouraging. While cost estimates were unavailable in the paper, the financial incentives offered were modest and the cost of providing services was likely to be relatively low as well (especially to the extent that they were integrated into the colleges’ existing programs). Opening Doors had effects that were at least as large as the state merit aid programs reviewed earlier. Still, sample sizes in the evaluations were relatively small, and caution is warranted until the results can be scaled up and replicated. Further research is needed on these promising programs. 
Several themes emerge from these experimental evaluations. First, the effect of aid appears to be greater than that of services. Interventions that offered services alone generally had weak impacts, whereas aid typically generated positive effects on enrollment and persistence. Second, aid has a larger impact when combined with services. In the STAR experiment, the only sustained gains were found in the treatment group that combined aid and services. The impact of Opening Doors (which combined aid and services) was proportionally larger than quasiexperimental estimates of aid alone from the studies reviewed in Section III.B.

\section{Discussion}

The effects of the financial aid programs we have discussed appear to depend critically on form taken by the intervention. Program design matters. In particular, there appears to be an important tradeoff between targeting and program effectiveness. Highly-targeted programs such as the Pell focus their dollars on poorer students, but impose substantial paperwork burdens in order to identify the neediest. If targeted students are deterred by administrative hurdles, these programs will not work as well as intended. This is consistent with the pattern in Table 1, in which the Pell and Stafford have small to zero effects while simpler, less-targeted programs have substantial effects.

The paperwork requirements of the federal, need-based aid programs are high. For the typical household, the aid application (the Free Application for Federal Student Aid, or FAFSA) is longer and more complicated than the federal tax return. The aid process is also highly uncertain, with definitive information about freshman-year aid not revealed until the spring of the senior year in high school. (Dynarski and Scott-Clayton, 2006). This process may be particularly daunting for low-income families. Parents in these families have typically not gone 
to college themselves, so cannot draw from their own experiences to help their children. Lowincome high school students have few guidance counselors to guide them through the process. They are unlikely to have Internet access at home and frequently speak English as a second language. As a result, need-based aid -- which requires gathering extensive information about income and expenses -- may have a smaller effect on this population than less-targeted forms of subsidy with fewer application requirements and lower transaction costs.

By contrast, Georgia’s HOPE scholarship requires only that high school students maintain a 3.0 GPA in order to have their tuition and fees paid at any public college in Georgia. High schools proactively send transcript data to the state in order to identify scholarship winners. For most students, the HOPE application consists of a half- page of basic biographical information. High school students are knowledgeable about HOPE. More than seventy percent of Georgia high-school freshmen surveyed were able to name the program without prompting. Fifty-nine percent, when asked to list some requirements of HOPE, volunteered that a high school GPA of 3.0 is necessary (Bugler and Henry, 1998). The compliance costs of the Social Security student benefit program were also minimal.

Promising recent evidence on the benefits of simplification comes from a randomized trial of assisted FAFSA completion conducted in partnership with H\&R Block, an accounting firm that provides tax preparation assistance (Bettinger, Long, Oreopoulos and Sanbonmatsu, 2009). Tax professionals pre-populated the FAFSA with income and asset information and assisted families with completion and filing of the form. The treatment group was also provided with an immediate estimate of aid eligibility and information about local postsecondary options and costs. Early results from the program suggest that assistance increased college enrollment substantially, both for recent high school graduates and for older, independent students with no 
college experience (Bettinger, Long, Oreopoulos and Sanbonmatsu 2009). The results suggest that simplification may be a highly cost-effective way to improve college access. In contrast, there was no effect for a second treatment group that received only information, with no assistance. This implies that compliance costs, rather than lack of information, may be the more important barrier. The results suggest that increases in educational attainment could be achieved at virtually no cost by making existing aid programs simpler and more transparent

In sum, the best evidence for effective financial aid on educational attainment comes from simple, broad-based programs. Given that most students in these programs are inframarginal, the benefits of simplicity versus targeting are an empirical question. The empirical evidence suggests that even broad-based programs may pass a social cost-benefit test. Dynarski (2008) estimates that state merit aid programs in Georgia and Arkansas pass a cost-benefit test if the return to schooling is between 5 and 9 percent. This is on the low end of instrumental variable rates of return to schooling, and is well below the rate of return estimated for recent cohorts (Angrist and Krueger 1991; Kane and Rouse 1995; Oreopoulos 2007.) Thus it appears that even with a low "effective" increase in enrollment due to subsidization of inframarginal students, a simple, broad-based aid program can increase social welfare.

Students who enter college but drop out without a degree are an important target for those who wish to increase educational attainment. Dropout rates are especially high at community colleges, where poor students are concentrated. Interventions that increase persistence in community colleges are therefore a sensible focus if the goal is to increase the educational attainment of the poor. The Opening Doors demonstration projects provide strong evidence that pairing financial incentives with support services can increase college persistence among low- 
income students attending community colleges. Testing the efficacy of these programs at scale is an important next step for researchers and policymakers. 


\section{References}

Abraham, Katharine and Melissa Clark (2006). "Financial Aid and Students' College Decisions: Evidence from the District of Columbia Tuition Assistance Grant Program.” Journal of Human Resources, Summer 2006, pp. 578-610.

Angrist, Joshua D. (1993). “The Effect of Veterans Benefits on Education and Earnings.” Industrial and Labor Relations Review 46:4, 637-52.

Angrist, Joshua D. and Alan B. Krueger (1991). "Does Compulsory School Attendance Affect Schooling and Earnings?” Quarterly Journal of Economics 106(4): 979-1014.

Angrist, Joshua D., Daniel Lang and Philip Oreopoulos (2009). "Incentives and Services for College Achievement: Evidence from a Randomized Trial.” American Economic Journal: Applied Economics 1(1): 136-163.

Avery, Christopher, Caroline Hoxby, Clement Jackson, Kaitlin Burek, Glenn Poppe and Mridula Raman (2006). "Cost Should Be No Barrier: An Evaluation of the First Year of Harvard's Financial Aid Initiative.” NBER Working Paper 12029.

Avery, Christopher and Thomas J. Kane (2004). "Student Perceptions of College Opportunities: The Boston COACH Program," in Caroline Hoxby, ed., College Choices: The Economics of Where to Go, When to Go, and How To Pay for It. Chicago: University of Chicago Press.

Bettinger, Eric (2004). "How Financial Aid Affects Persistence,” in Caroline Hoxby, ed., College Choices: The Economics of Where to Go, When to Go, and How To Pay for It. Chicago: University of Chicago Press.

Bettinger, Eric, Bridget Terry Long, Philip Oreopoulos and Lisa Sanbonmatsu (2009). “The Role of Information and Simplification in College Decisions: Results from the H\&R Block FAFSA Experiment.” Working Paper.

Bloom, Dan and Colleen Sommo (2005). "Building Learning Communities: Early Results from the Opening Doors Demonstration at Kingsborough Community College.” MDRC, New York, NY.

Bok, Derek and William G. Bowen (2000). The Shape of the River: Long-Term Consequences of Considering Race in College and University Admissions. Princeton University Press, Princeton NJ.

Bound, John and Sarah Turner (2002). "Going to War and Going to College: Did World War II and the G.I. Bill Increase Educational Attainment for Returning Veterans?” Journal of Labor Economics 20 (4): 784-815. 
Brock, Thomas and Lashawn Richburg-Hayes (2006). "Paying for Persistence: Early Results of a Louisiana Scholarship Program for Low-Income Parents Attending Community College.” Manpower Development Research Corp., New York NY.

Bugler, Daniel T. and Gary T. Henry (1998). “An Evaluation of Georgia’s HOPE Scholarship Program: Impact on College Attendance and Performance.” Council for School Performance, Georgia State University.

College Board (2005). Education Pays 2005. The College Board, New York, NY.

Cornwell, Christopher, David Mustard and Deepa Sridhar (2006). "The Enrollment Effects of Merit-Based Financial Aid: Evidence from Georgia’s HOPE Scholarship.” Journal of Labor Economics 24, 761-786.

DesJardins, Stephen L. and Brian P. McCall (2007). “The Impact of the Gates Millenium Scholars Program on Selected Outcomes of Low-Income Minority Students: A Regression Discontinuity Analysis.” Working Paper.

Dynarski, Susan (2000). "Hope for Whom? Financial Aid for the Middle Class and Its Impact on College Attendance.” National Tax Journal 53:3 (September), pp. 629-661.

Dynarski, Susan (2002). "The Behavioral and Distributional Implications of Aid for College.” American Economic Review (May).

Dynarski, Susan (2003). "Does Aid Matter? Measuring the Effect of Student Aid on College Attendance and Completion.” American Economic Review (March).

Dynarski, Susan (2004)"Who Benefits from the College Saving Incentives? Income, Educational Expectations and the Value of the 529 and Coverdell." National Tax Journal (September).

Dynarski, Susan (2005). “Loans, Liquidity and Schooling Decisions.” Mimeo, Harvard University.

Dynarski, Susan (2008). "Building the Stock of College-Educated Labor.” Journal of Human Resources (Summer).

Dynarski, Susan and Judith Scott-Clayton (2006a). "Simplify and Focus the Education Tax Incentives." Tax Notes.

Dynarski, Susan and Judith Scott-Clayton (2006b). "The Cost of Complexity in Federal Student Aid: Lessons from Optimal Tax Theory and Behavioral Economics.” National Tax Journal (June).

Goodman, Joshua (2008). "Who merits financial aid?: Massachusetts’ Adams Scholarship”, Journal of Public Economics 92(10-11): 2121-2131.

Hansen, W. Lee (1983). “The Impact of Student Financial Aid on Access.” In Joseph Froomkin, ed., The Crisis in Higher Education. New York: Academy of Political Science. 
Heller, Donald E. (1997), "Student Price Response in Higher Education: An Update to Leslie and Brinkman.” Journal of Higher Education 68(6).

Kane, Thomas J. (1995). "Rising Public College Tuition and College Entry: How Well Do Public Subsidies Promote Access to College?” National Bureau of Economic Research Working Paper 5164.

Kane, Thomas J. (2003). “A Quasi-Experimental Estimate of the Impact of Financial Aid on College-Going.” National Bureau of Economic Research Working Paper 9703.

Kane, Thomas J. (2004). "Evaluating the Impact of the D.C. Tuition Assistance Grant Program.” National Bureau of Economic Research Working Paper 10658.

Kane, Thomas J. (2007). "Evaluating the Impact of the D.C. Tuition Assistance Grant Program.” Journal of Human Resources 42(3): 555-582.

Kane, Thomas J. and Cecilia E. Rouse (1995). "Labor Market Returns to Two- and Four-Year College.” American Economic Review 85(3): 600-614.

Leslie, Larry and Paul Brinkman (1988). The Economic Value of Higher Education. New York: Macmillan.

Linsenmeier, David M., Harvey S. Rosen, and Cecilia Elena Rouse (2006). "Financial Aid Packages and College Enrollment Decisions: An Econometric Case Study.” Review of Economics and Statistics 88:1, pp. 126-145.

Myers, David and Allen Schirm (1999). The Impacts of Upward Bound: Final Report for Phase I of the National Evaluation. Mathematica Policy Research, Washington DC.

Myers, David, Rob Olsen, Neil Seftor, Julie Young and Christina Tuttle (2004). The Impacts of Regular Upward Bound: Results from the Third Follow-Up Data Collection. Mathematica Policy Research, Washington DC.

Oreopoulos, Philip (2007). "Do dropouts drop out too soon? Wealth, health and happiness from compulsory schooling.” Journal of Public Economics, 91(11-12): 2213-2229.

Pallais, Amanda and Sarah E. Turner (2007). “Access to Elites,” in Economic Inequality and Higher Education: Access, Persistence and Success, eds. Stacy Dickert-Conlin and Ross H. Rubenstein, Russell Sage Foundation, New York NY.

Rothstein, Jesse and Cecilia E. Rouse (2007). "Constrained After College: Student Loans and Early Career Occupational Choices.” National Bureau of Economic Research Working Paper 13117.

Scott-Clayton, Judith (2009). “On Money and Motivation: A Quasi-Experimental Analysis of Financial Incentives for College Achievement.” Working Paper. 
Scrivener, Susan et al (2008). "A Good Start: Two-Year Effects of a Freshman Learning Community Program at Kingsborough Community College.” Manpower Development Research Corp., New York NY.

Scrivener, Susan and Jenny Au (2007). "Enhancing Student Services at Lorain County Community College: Early Results from the Opening Doors Demonstration in Ohio.” Manpower Development Research Corp., New York NY.

Scrivener, Susan and Michael Pih (2007). "Enhancing Student Services at Owens Community College: Early Results from the Opening Doors Demonstration in Ohio.” Manpower Development Research Corp., New York NY.

Seftor, Neil and Sarah Turner (2002). "Back to School: Federal Student Aid Policy and Adult College Enrollment.” Journal of Human Resources.

Stanley, Marcus (2003). “College Education and the Mid- Century G.I. Bills.” Quarterly Journal of Economics 118(2): 671-708.

Stedman, James B. (2003). Federal Pell Grant Program of the Higher Education Act: Background and Reauthorization. Congressional Research Service, Washington DC.

Reyes, Suzanne L. (1995). "Educational Opportunities and Outcomes: The Role of the Guaranteed Student Loan.” Mimeo, Harvard University.

Turner, Sarah. 2007. "Higher education: Policies Generating the 21st Century Workforce," in Harry Holzer and Demetra Nightingale, eds., Workforce Policies for a Changing Economy. Washington, D.C.: Urban Institute Press.

Turner, Sarah and John Bound (2003). "Closing the Gap or Widening the Divide: The Effects of the G.I. Bill and World War II on the Educational Outcomes of Black Americans." Journal of Economic History 63:1, pp. 145-177.

van der Klaauw, Wilbert (2002). "Estimating the Effect of Financial Aid Offers on College Enrollment: A Regression-Discontinuity Approach.” International Economic Review 43:4, pp. 1249-1288. 
Table 1: Summary of Studies

\begin{tabular}{|c|c|c|c|c|c|c|}
\hline \multicolumn{7}{|c|}{ Experimental Studies } \\
\hline Study & Sample & Intervention/Method & $\begin{array}{c}\text { Financial } \\
\text { Award }\end{array}$ & $\begin{array}{c}\text { Evaluation } \\
\text { Design }\end{array}$ & Outcomes & Effects \\
\hline $\begin{array}{l}\text { STAR - Canada } \\
\text { (Angrist et al, 2007) }\end{array}$ & $\begin{array}{l}\sim 1600 \text { entering } \\
\text { freshman at a public } \\
\text { university in Canada, } \\
\text { satellite campus }\end{array}$ & $\begin{array}{l}3 \text { treatment groups }-1 \text { ) peer } \\
\text { advising and organized study } \\
\text { group; 2) a merit scholarship for } \\
\text { above-avg. grades; 3) both }\end{array}$ & $\begin{array}{l}\text { yes }-\$ 5000 \\
\text { for a } 3.0 \text { avg., } \\
\$ 1000 \text { for a } \\
2.3 \text { avg. }\end{array}$ & $\begin{array}{l}\text { randomized } \\
\text { experiment }\end{array}$ & grades, retention & $\begin{array}{l}\text { Largest effect for combined group - } 0.1-0.2 \\
\text { SD increase in grades; } 4-5 \text { percentage point } \\
\text { decrease in probation. No effect on retention } \\
\text { for any group. Weak/no effects for groups } 1 \\
\text { and 2; no effect for males in any group. }\end{array}$ \\
\hline $\begin{array}{l}\text { Opening Doors - New } \\
\text { York (Bloom and } \\
\text { Sommo, 2005; } \\
\text { Scrivener et al 2008) }\end{array}$ & $\begin{array}{l}\sim 750 \text { Community } \\
\text { College Attendees, } \\
\text { mixed races, mostly } \\
\text { immigrant }\end{array}$ & $\begin{array}{l}\text { Learning Communities - } \\
\text { organized cohort of entering } \\
\text { students into same classes; } \\
\text { improved counseling and } \\
\text { monitoring; instructors work } \\
\text { together }\end{array}$ & $\begin{array}{l}\text { no - (except } \\
\text { textbook } \\
\text { voucher) }\end{array}$ & $\begin{array}{l}\text { randomized } \\
\text { experiment }\end{array}$ & $\begin{array}{l}\text { Credits taken } \\
\text { and earned; pass } \\
\text { rate and GPA; } \\
\text { retention }\end{array}$ & $\begin{array}{l}8 \text { percentage points less likely to withdraw } \\
\text { and } 10 \text { point increase in pass rate; cumulative } \\
\text { impact of } 2.4 \text { credits and } 0.1 \text { semesters; } 5 \\
\text { percentage point increase in enrollment post- } \\
\text { program }\end{array}$ \\
\hline $\begin{array}{l}\text { Opening Doors - } \\
\text { Louisiana (Brock and } \\
\text { Richburg-Hayes, } \\
\text { 2006) }\end{array}$ & $\begin{array}{l}\text { \%00 Community } \\
\text { College Attendees, } \\
\text { mostly female and } \\
\text { African-American }\end{array}$ & $\begin{array}{l}\text { Financial Aid; Improved } \\
\text { counseling and monitoring }\end{array}$ & $\begin{array}{l}\text { yes }-\$ 1000 \\
\text { per semester } \\
\text { for } 1 / 2 \text { time } \\
\text { enrollment } \\
\text { and } 2.0 \mathrm{GPA}\end{array}$ & $\begin{array}{l}\text { randomized } \\
\text { experiment }\end{array}$ & $\begin{array}{l}\text { Credits taken } \\
\text { and earned; pass } \\
\text { rate and GPA; } \\
\text { retention }\end{array}$ & $\begin{array}{l}7 \text { percentage points less likely to withdraw } \\
\text { and } 12 \text { point increase in pass rate; cumulative } \\
\text { increase of } 3.3 \text { credits and } 0.3 \text { semesters; } 11 \\
\text { percentage point increase in post-program } \\
\text { enrollment }\end{array}$ \\
\hline $\begin{array}{l}\text { Opening Doors - Ohio } \\
\text { (Scrivener and Au } \\
\text { 2007; Scrivener and } \\
\text { Pih 2007) }\end{array}$ & $\begin{array}{l}\sim 1000 \text { Community } \\
\text { College Attendees, } \\
\text { mostly female and } \\
\text { mixed race }\end{array}$ & $\begin{array}{l}\text { Multiple mandatory meetings } \\
\text { with counselors; aid award given } \\
\text { for attendance }\end{array}$ & $\begin{array}{l}\text { yes }-\$ 150 \text { per } \\
\text { semester }\end{array}$ & $\begin{array}{l}\text { randomized } \\
\text { experiment }\end{array}$ & $\begin{array}{l}\text { Credits taken } \\
\text { and earned; pass } \\
\text { rate and GPA; } \\
\text { retention }\end{array}$ & $\begin{array}{l}\text { no effect on withdrawal or pass rate; } \\
\text { cumulative increase of } 0.8 / 1.0 \text { credits and } \\
0.1 / 0.2 \text { semesters; } 5.6 / 10.5 \text { percentage point } \\
\text { increase in post-program enrollment }\end{array}$ \\
\hline
\end{tabular}




\begin{tabular}{|c|c|c|c|c|c|c|}
\hline \multicolumn{7}{|c|}{ Quasi-Experimental Studies } \\
\hline Study & Sample & Intervention/Method & $\begin{array}{c}\text { Financial } \\
\text { Award }\end{array}$ & $\begin{array}{l}\text { Evaluation } \\
\text { Design }\end{array}$ & Outcomes & Effects \\
\hline $\begin{array}{l}\text { Introduction of Pell } \\
\text { Grant Program } \\
\text { (Hansen 1983; Kane } \\
\text { 1995) }\end{array}$ & $\begin{array}{l}\text { October Current } \\
\text { Population Survey; } \\
\text { 1970-1977 }\end{array}$ & $\begin{array}{l}\text { Compare enrollment of eligible } \\
\text { to non-eligible population, before } \\
\text { and after } 1973 \text { when the Pell } \\
\text { Grant was established }\end{array}$ & $\begin{array}{l}\text { yes - } \\
\text { maximum of } \\
\text { \$3544 in } 1991 \\
\text { dollars }\end{array}$ & $\begin{array}{l}\text { differences-in- } \\
\text { differences }\end{array}$ & $\begin{array}{l}\text { College } \\
\text { enrollment and } \\
\text { type }\end{array}$ & no effect \\
\hline $\begin{array}{l}\text { Change/discontinuity } \\
\text { in Pell Grant eligibility } \\
\text { (Seftor and Turner } \\
\text { 2002; Bettinger 2004) }\end{array}$ & $\begin{array}{l}\text { October Current } \\
\text { Population Survey; } \\
1969-1977 \text { and 1984- } \\
1990 \text { - "nontraditional" } \\
\text { older students only }\end{array}$ & $\begin{array}{l}\text { Same as Kane (1995), plus a } \\
\text { before/after comparison when } \\
\text { independent student definition } \\
\text { changed; Student Aid Index that } \\
\text { determines eligibility is estimated } \\
\text { directly from data }\end{array}$ & $\begin{array}{l}\text { yes - } \\
\text { maximum of } \\
\$ 3544 \text { in } 1991 \\
\text { dollars }\end{array}$ & $\begin{array}{l}\text { differences-in- } \\
\text { differences }\end{array}$ & Enrollment & $\begin{array}{l}\sim 1.5 \text { percentage point increase for initial Pell } \\
\text { introduction; 4 percentage points for } 2 \text { nd } \\
\text { change }\end{array}$ \\
\hline $\begin{array}{l}\text { Tuition Changes } \\
\text { (Kane 1995) }\end{array}$ & $\begin{array}{l}\text { CPS; NLSY-79; High } \\
\text { School and Beyond }\end{array}$ & $\begin{array}{l}\text { Between and within-state } \\
\text { variation in public subsidization } \\
\text { of college }\end{array}$ & $\begin{array}{l}\text { changes in } \\
\text { tuition sticker } \\
\text { price }\end{array}$ & $\begin{array}{l}\text { State fixed } \\
\text { effects }\end{array}$ & Enrollment & $\begin{array}{l}\sim 4 \text { percentage points per } \$ 1000 \text { drop in } \\
\text { tuition }\end{array}$ \\
\hline $\begin{array}{l}\text { Expansion of Stafford } \\
\text { Loan eligibility (Reyes } \\
\text { 1995; Dynarski 2005) }\end{array}$ & $\begin{array}{l}\text { October CPS 1984- } \\
2000 \text { and the Survey of } \\
\text { Income and Program } \\
\text { Participation (SIPP) } \\
\text { 1986-1996 }\end{array}$ & $\begin{array}{l}\text { Before/after } 1992 \text { legal change - } \\
\text { home equity no longer "taxed" in } \\
\text { the federal student aid formula }\end{array}$ & $\begin{array}{l}\text { yes - reduced } \\
\text { expected } \\
\text { contribution } \\
\text { by } \$ 2400 \text { for } \\
\text { family with } \\
\text { median equity }\end{array}$ & $\begin{array}{l}\text { differences-in- } \\
\text { differences }\end{array}$ & Enrollment & $\begin{array}{l}5.1 \text { percentage points per } \$ 1000 \text { of loan } \\
\text { subsidy in the CPS; imprecise/no effect in } \\
\text { SIPP; Reyes - } 1.5 \text { percentage points per } \\
\$ 1000\end{array}$ \\
\hline $\begin{array}{l}\text { GI Bill (Angrist 1993; } \\
\text { Stanley 2000; Bound } \\
\text { and Turner 2003; } \\
\text { Turner and Bound } \\
\text { 2003) }\end{array}$ & $\begin{array}{l}\text { Survey of } \\
\text { Occupational Change } \\
\text { in a Generation, 1973; } \\
\text { US Census }\end{array}$ & $\begin{array}{l}\text { Compare enrollment of military } \\
\text { enlistees before/during/after } \\
\text { eligibility periods }\end{array}$ & $\begin{array}{l}\text { yes - fully } \\
\text { subsidized } \\
\text { college } \\
\text { attendance } \\
\text { plus living } \\
\text { stipend }\end{array}$ & $\begin{array}{l}\text { between/within } \\
\text { cohorts }\end{array}$ & $\begin{array}{l}\text { total years of } \\
\text { educational } \\
\text { attainment }\end{array}$ & $\begin{array}{l}\sim 0.25 \text { years of education, or a } 5-6 \text { percentage } \\
\text { point increase in attendance due to Korean } \\
\text { War and WW II GI Bills }\end{array}$ \\
\hline
\end{tabular}




\begin{tabular}{|c|c|c|c|c|c|c|}
\hline \multicolumn{7}{|c|}{ Quasi-Experimental Studies (cont'd) } \\
\hline Study & Sample & Intervention/Method & $\begin{array}{c}\text { Financial } \\
\text { Award }\end{array}$ & $\begin{array}{c}\text { Evaluation } \\
\text { Design }\end{array}$ & Outcomes & Effects \\
\hline $\begin{array}{l}\text { Social Security } \\
\text { Student Benefits } \\
\text { (Dynarski 2003) }\end{array}$ & $\begin{array}{l}\text { National Longitudinal } \\
\text { Survey of Youth-1979 }\end{array}$ & $\begin{array}{l}\text { Elimination of the program in } \\
1981 \text { - compared those with } \\
\text { deceased father before and after }\end{array}$ & $\begin{array}{l}\text { yes - average } \\
\text { annual } \\
\text { payment was } \\
\$ 6700 \text { in } 1980 \\
\text { dollars }\end{array}$ & $\begin{array}{l}\text { differences-in- } \\
\text { differences }\end{array}$ & Enrollment & 3.6 percentage points per $\$ 1000$ of grant aid \\
\hline $\begin{array}{l}\text { State Merit Aid } \\
\text { Programs - Georgia } \\
\text { HOPE scholarship } \\
\text { (Dynarski 2000; } \\
\text { Cornwell et al 2006) }\end{array}$ & $\begin{array}{l}\text { CPS and Integrated } \\
\text { Postsecondary } \\
\text { Education Data System } \\
\text { (IPEDS) 1988-1997 }\end{array}$ & $\begin{array}{l}\text { Before/after institution of a } \\
\text { statewide merit (3.0 GPA } \\
\text { minimum) scholarship in } 1993\end{array}$ & $\begin{array}{l}\text { yes - tuition } \\
\text { and required } \\
\text { fees at public } \\
\text { institutions in } \\
\text { GA }\end{array}$ & $\begin{array}{l}\text { differences-in- } \\
\text { differences }\end{array}$ & $\begin{array}{l}\text { enrollment; } \\
\text { college choice }\end{array}$ & $\begin{array}{l}\text { 4-6 percentage points per } \$ 1000 \text { of grant aid; } \\
\text { increase in enrollment in GA schools }\end{array}$ \\
\hline $\begin{array}{l}\text { State Merit Aid } \\
\text { Program - CAL Grant } \\
\text { (Kane 2003) }\end{array}$ & $\begin{array}{l}\text { Administrative Data } \\
\text { from California and } \\
\text { the National Student } \\
\text { Clearinghouse }\end{array}$ & $\begin{array}{l}\text { Discontinuous changes in the } \\
\text { eligibility formula for Cal Grants }\end{array}$ & $\begin{array}{l}\text { yes - tuition } \\
\text { and required } \\
\text { fees at public } \\
\text { institutions or } \\
\text { a private } \\
\text { school grant of } \\
\sim \$ 9 \mathrm{k}\end{array}$ & $\begin{array}{l}\text { regression } \\
\text { discontinuity }\end{array}$ & Enrollment & $\begin{array}{l}\text { 3-4 percentage point increase (among those } \\
\text { who applied for financial aid) for those } \\
\text { eligible for Cal Grant A }\end{array}$ \\
\hline $\begin{array}{l}\text { State Merit Aid } \\
\text { Program - Adams } \\
\text { Scholarship (Goodman } \\
\text { 2008) }\end{array}$ & $\begin{array}{l}\text { Administrative Data } \\
\text { from Massachusetts } \\
\text { Department of } \\
\text { Education }\end{array}$ & $\begin{array}{l}\text { Discontinuous Change in } \\
\text { eligibility based on test score } \\
\text { cutoff; Before/After institution of } \\
\text { merit aid program }\end{array}$ & $\begin{array}{l}\text { Yes - tuition } \\
\text { waiver at MA } \\
\text { public } \\
\text { schools; } \\
\sim \$ 1575 \text { per } \\
\text { year at } 4 \text { yr. }\end{array}$ & $\begin{array}{l}\text { Regression } \\
\text { discontinuity / } \\
\text { differences-in- } \\
\text { differences }\end{array}$ & Enrollment & $\begin{array}{l}6 \% \text { of winners switched from private to } \\
\text { public } 4 \text {-year colleges; no impact on overall } \\
\text { enrollment }\end{array}$ \\
\hline
\end{tabular}




\begin{tabular}{|c|c|c|c|c|c|c|}
\hline \multicolumn{7}{|c|}{ Quasi-Experimental Studies (cont'd) } \\
\hline Study & Sample & Intervention/Method & $\begin{array}{c}\text { Financial } \\
\text { Award }\end{array}$ & $\begin{array}{c}\text { Evaluation } \\
\text { Design }\end{array}$ & Outcomes & Effects \\
\hline $\begin{array}{l}\text { DC Tuition Assistance } \\
\text { Grant (Kane 2004; } \\
\text { Abraham and Clark } \\
\text { 2006) }\end{array}$ & $\begin{array}{l}\text { IPEDS; Department of } \\
\text { Ed. FAFSA data; } \\
\text { DCTAG } \\
\text { administrative records; } \\
\text { SAT data }\end{array}$ & $\begin{array}{l}\text { Allowed DC residents to attend } \\
\text { public schools in other states and } \\
\text { pay in-state tuition }\end{array}$ & $\begin{array}{l}\text { yes - } \\
\text { difference } \\
\text { between out } \\
\text { and in-state } \\
\text { tuition (up to } \\
\$ 10 \mathrm{k} \text { ) }\end{array}$ & $\begin{array}{l}\text { differences-in- } \\
\text { differences }\end{array}$ & $\begin{array}{l}\text { enrollment; } \\
\text { college location } \\
\text { and type }\end{array}$ & $\begin{array}{l}\sim 3-4 \text { percentage point increase per } \$ 1000 \\
\text { effective tuition reduction; fraction of DC } \\
\text { residents at MA and VA colleges more than } \\
\text { doubled }\end{array}$ \\
\hline $\begin{array}{l}\text { State Merit Aid } \\
\text { Program - } \\
\text { Multiple/Other } \\
\text { (Dynarski 2004; } \\
\text { Dynarski 2008; Scott- } \\
\text { Clayton 2009) }\end{array}$ & $\begin{array}{l}\text { Current Population } \\
\text { Survey; WV State } \\
\text { Administrative Data }\end{array}$ & $\begin{array}{l}\text { Merit Aid programs in GA and } \\
\text { other states - before/after creation } \\
\text { of each program; West Virginia } \\
\text { PROMISE scholarship }\end{array}$ & $\begin{array}{l}\text { varies - } \\
\text { usually tuition } \\
\text { and fees at a } \\
\text { state public } \\
\text { school or } \\
\text { equivalent } \\
\text { voucher for } \\
\text { private }\end{array}$ & $\begin{array}{l}\text { differences-in- } \\
\text { differences; } \\
\text { regression } \\
\text { discontinuity }\end{array}$ & $\begin{array}{l}\text { enrollment; } \\
\text { college type; } \\
\text { completion }\end{array}$ & $\begin{array}{l}\sim 5-7 \text { average percentage point increase in } \\
\text { enrollment due to state programs; shift away } \\
\text { from } 2 \text { and toward } 4 \text {-year schools; 3-4 } \\
\text { percentage point increase in degree } \\
\text { completion ( } 6 \text { percentage point increase in } \\
\text { on-time graduation in for PROMISE } \\
\text { recipients - linked to credit requirements) }\end{array}$ \\
\hline $\begin{array}{l}\text { Effect of School Aid } \\
\text { on Yield Rate (van der } \\
\text { Klaauw 2002; } \\
\text { Linsenmeier et al } \\
\text { 2006) }\end{array}$ & $\begin{array}{l}\text { Administrative Data } \\
\text { from anonymous } \\
\text { colleges, 1989-1993 } \\
\text { and } 1998\end{array}$ & $\begin{array}{l}\text { Discontinuous changes in the } \\
\text { formula for aid allocation; } \\
\text { before/after shift from loan/grant } \\
\text { mix to grants only }\end{array}$ & $\begin{array}{l}\text { merit grants } \\
\text { for students of } \\
\text { higher ability } \\
\sim \$ 2000 \text { on } \\
\text { average; full } \\
\text { tuition }\end{array}$ & $\begin{array}{l}\text { regression } \\
\text { discontinuity; } \\
\text { differences-in- } \\
\text { differences }\end{array}$ & Enrollment & $\begin{array}{l}\sim 4 \text { percentage points per } \$ 1000 \text { in grant aid; } \\
\text { no impact on enrollment overall, but } 8-10 \\
\text { percentage points for minorities }\end{array}$ \\
\hline $\begin{array}{l}\text { Gates Millenium } \\
\text { Scholars (DesJardins } \\
\text { and McCall 2007) }\end{array}$ & $\begin{array}{l}\text { National Opinion } \\
\text { Research Center } \\
\text { survey of program } \\
\text { participants }\end{array}$ & $\begin{array}{l}\text { Discontinuous change in } \\
\text { eligibility based on an } \\
\text { application "cut score" }\end{array}$ & $\begin{array}{l}\text { "tops up" diff } \\
\text { between need- } \\
\text { based aid and } \\
\text { price of } \\
\text { college }\end{array}$ & $\begin{array}{l}\text { regression } \\
\text { discontinuity }\end{array}$ & $\begin{array}{l}\text { retention; loan } \\
\text { debt; hours } \\
\text { worked }\end{array}$ & $\begin{array}{l}\text { no impact on retention; } 60 \% \text { less debt; } 35 \% \\
\text { fewer hours worked }\end{array}$ \\
\hline
\end{tabular}


Figure 2a: Median Annual Earnings of Males and Females Ages 25-34 by Education Level, 1972-2003 (Constant 2003 Dollars)

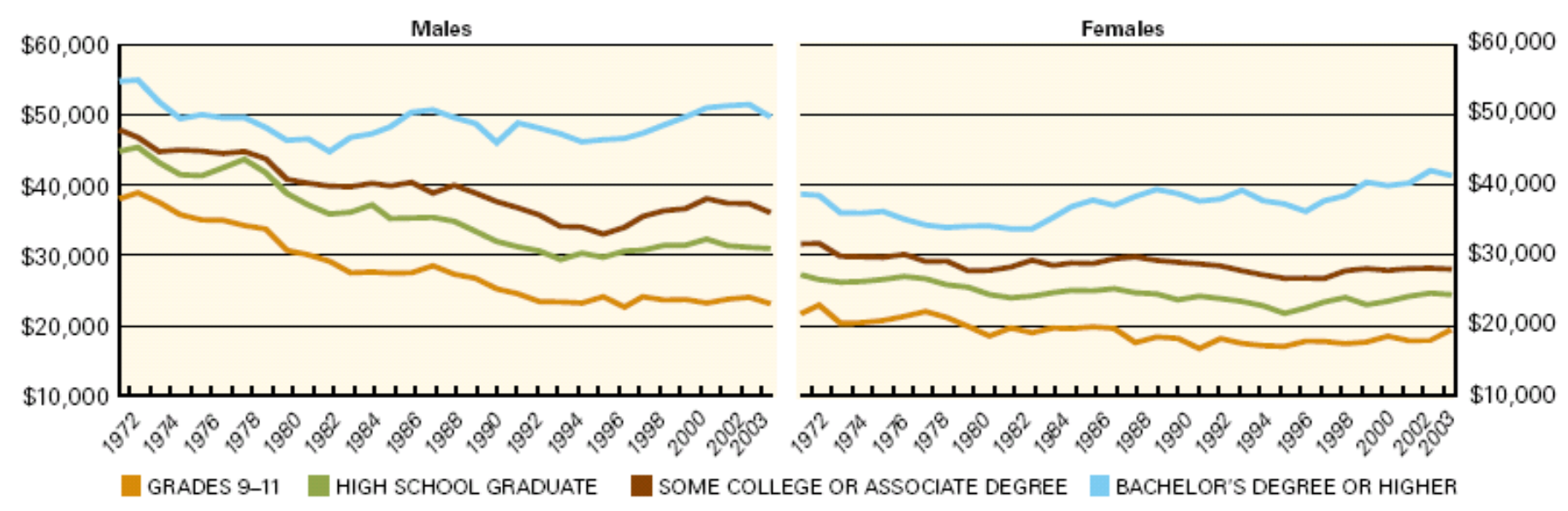

Note: Includes full-time, full-year workers.

Sources: National Center for Education Statistics (NCES), 2005a, Indicator 14 (based on U.S. Census Bureau, Current Population Survey, March Supplement, 1972-2003) and unpublished data.

Figure 2b: Years of Schooling Completed by People 25 and Older, 1940-2004

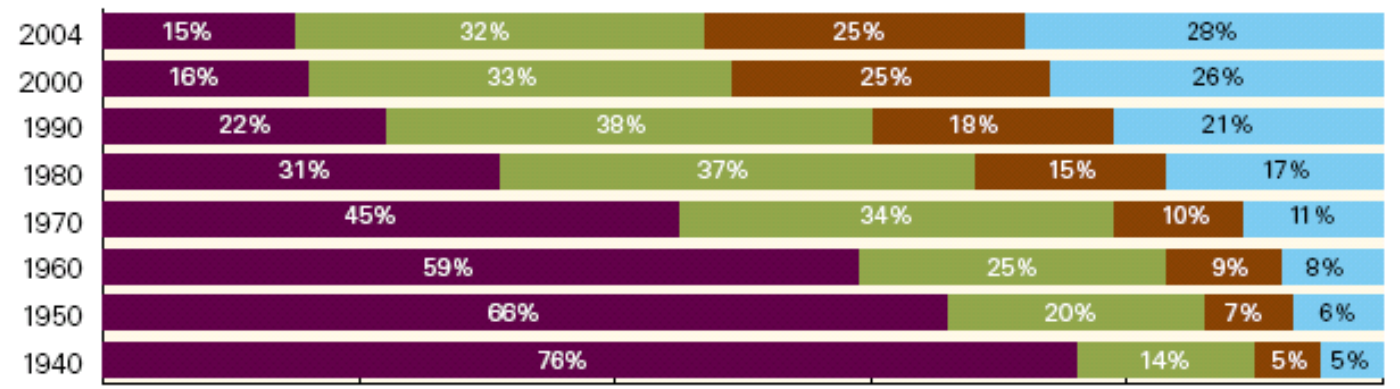

Note: Percents may not sum to 100 percent due to rounding. Source: U.S. Census Bureau, 2005, Table A-1.

NOT A HIGH SCHOOL GRADUATE

HIGH SCHOOL GRADUATE

- SOME COLLEGE OR ASSOCIATE DEGREE BACHELOR'S DEGREE OR HIGHER 